\title{
Opportunistic Diseases as a Consequence of HIV/AIDS
}

\author{
Soumya $\mathrm{D}^{1 *}$ and Hima Bindu $\mathrm{A}^{2}$ \\ ${ }^{1}$ Department of Microbiology, Chaitanya Postgraduate College, Kakatiya University, Warangal, India \\ ${ }^{2}$ Department of Biotechnology, Andhra Vidyalaya P.G College, Osmania University, Hyderabad, India
}

\begin{abstract}
Acquired Immuno Deficiency Syndrome is a major threatening disease occurring in humankind, caused by Human Immunodeficiency Virus. With the progression of HIV infection, the immune system of the infected gets weakened as the virus attacks immune system and impairs the function of immune cells. Hence several pathogens take the opportunity to invade the host. Present review focuses on the advancement of HIV and opportunistic illnesses caused by various pathogenic organisms. Opportunistic diseases do not often affect healthy individuals with potential immune system where as individuals with weakened immune system are highly affected. Inspite of various therapies used to treat AIDS; it may also lead to opportunistic infections.
\end{abstract}

Keywords: Acquired Immuno Deficiency Syndrome; HIV infection; Opportunistic diseases; Bacterial Infections; Fungal Infections; Viral Infections

Abbreviations: AIDS: Acquired Immuno Deficiency Syndrome; OI: Opportunistic infections; HIV: Human Immunodeficiency Virus; CD4: cluster of differentiation 4

\section{Introduction}

AIDS, also called Acquired Immuno Deficiency Syndrome is a major dreadful disease occurring in humankind. AIDS is the advanced state of HIV infection which can take 10-15 years to develop. HIV is a chronic medical condition that can be treated, but not yet cured. There are effective ways to prevent complications and delay, but not always prevent progression to AIDS. Human Immunodeficiency Virus (HIV) belonging to subset of retroviruses [1] called lentiviruses [2] (or slow viruses) is the causal agent of AIDS. The transmission of virus [3] can be through sexual contact, blood transfusions or using the disinfected needles, and also from mother to child in a pregnant woman through blood circulation i.e. HIV infected women co-infected with opportunistic diseases can transform it to their infants. Also HIV can be a risk factor in injection drug users [4], a prevalent infection and also Male-to-female transgender adolescents [5]. In this case CD4 cell count [6] decreases i.e. the cells of immune system which is the important factors for progression of HIV infection. CD4 cells are important in defense mechanisms and natural killer cells [7] are important in controlling tumors and cytomegalovirus (CMV), mycobacterial and fungal infections.

The virus attacks immune system, impairs the function of immune cells and is finally responsible for lowering the capability of it. Hence immune system fails to respond to various pathological conditions and infections. Due to the weakened immune system the body will be affected by various infections, there by leads to the death finally person. Several infections originate with AIDS known as opportunistic infections. They are so called as they take advantage of the opportunity to infect a weakened or immunodeficient host. Opportunistic diseases do not often affect healthy individuals with potential immune system where as individuals with weakened immune system are highly affected. HIV/AIDS remains the greatest public health crises in the world today.

Pediatric HIV infection [8] is also prevalent in most of the places. Sexual assaults [9] in children are a major concern in South Africa leading to HIV. The global AIDS epidemic [10] has advanced without lessening for about 30 years with about 36 million people having chronic HIV-1 infections and about 36 million who have already succumbed to AIDS. In several countries AIDS is the burning problem. In subSaharan Africa [11] it is estimated that around 25.8 million adults and children are infected with HIV along with chronic diarrhoea. In Tanzania [12] HIV and AIDS remains a significant problem with an adult prevalence rate of $8.8 \%$.

\section{Risk of Opportunistic Diseases in AIDS}

The nature of HIV and AIDS is complex [13]. AIDS is characterized by various complications including opportunistic infections neurological impairment, and malignancies and also some types of cancers that origin with the advancement of HIV. The infections include: Fungal infections, Bacterial infections, viral infections, parasitic infections and malignancies. Opportunistic diseases increase the risk of death [14] apart from HIV alone and significantly reduce the quality of life and longevity [15]. Due to the immune deficiency, the infected person would be susceptible to many infections and the risk would be high in people with weakened immune system. Hence the individuals with AIDS are affected and leads to death.

\section{Prevalent Complications or Infections}

According to recent studies it is clear that Tuberculosis [16] is the most predominant infection and then oral candidiasis occupies the position. Among HIV/ AIDS infected persons. Problematic headache is one of the highly prevalent complications. Also cardiovascular diseases [17], Neurocognitive diseases [18] can be associated with HIV infection. Human immunodeficiency virus (HIV) infection has been associated with rhabdomyolysis [19].

Corresponding author: Soumya D, Department Of Microbiology, Chaitanya Postgraduate College, affiliated to Kakatiya University, Warangal, India, E-mail: soumya.naidu22@gmail.com

Received October 20, 2011; Accepted December 02, 2011; Published December 15, 2011

Citation: Soumya D, Hima Bindu A (2011) Opportunistic Diseases as a Consequence of HIVIAIDS. J AIDS Clinic Res 2:133. doi:10.4172/2155-6113.1000133

Copyright: $\odot 2011$ Soumya D, et al. This is an open-access article distributed unde the terms of the Creative Commons Attribution License, which permits unrestricted use, distribution, and reproduction in any medium, provided the original author and source are credited. 


\section{Fungal Infections}

Candida sps are the most threatening species causing fungal infections in AIDS patients. They are found on the mucosal surfaces of the mouth, the gut, and the female reproductive system. Thrush or Candidiasis is caused by Candida sps. Oral candidiasis [20] is often seen with HIV infection and may presage the progression to AIDS. Candida can also spread and cause infection in the brain, heart, joints, and eyes. It can occasionally produce invasive infections in esophagus, upper respiratory tract, and lung. In esophageal candidiasis there is a chance of presenting headache and tremors [21].

Yeast causes infection to the esophagus which causes pain with swallowing. On the basis of clinical symptoms [22] of candidiasis HIV infection can be diagnosed. Infections with the pathogenic fungi Cryptococcus neoformans, Histoplasma capsulatum and Coccidioides immitis are more serious infections that are often widely disseminated. C neoformans often produces pneumonia and fungal meningoencephalitis [23] or fungal meningitis, an infection that causes inflammation of the membranes covering the brain and spinal cord, is one of the most common life-threatening opportunistic infections of HIV patients. Histoplasma capsulatum, a fungus is responsible for Histoplasmosis [24] which is characterized by fever, cough, anemia, and other related problems. Disseminated histoplasmosis [25] is associated with Acquired Immunodeficiency Syndrome (AIDS). African histoplasmosis [26] is a rare histoplasmosis with Histoplasma duboisii in patients with AIDS. Histoplasmosis and the illness manifestations are indistinguishable from tuberculosis [27].

In women infected with HIV, Vulvovaginal candidiasis (VVC) [28] is most common fungal infection. However in women, mucosal tissues or mucosal surfaces maintain a vigilant and vigorous immunity [29] against pathogenic intruders. Dermatophytic infections are common in HIV-infected patients and atypical forms of cutaneous fungal infections are common in patients with AIDS. Fungal infections of the musculoskeletal system [30] are uncommon. Sinuses are present underlying the skin of infected person. Pneumocytis Pneumonia caused by Pneumocystis was one of the first unusual infections observed early in the AIDS epidemic, which causes wheezing and dry cough. Invasive Aspergillosis [31] occurs in advanced AIDS and usually affects the lungs, and brain. Several Aspergillus species cause infections. It is difficult to estimate the incidence of aspergillus infections in AIDS patients.

\section{Bacterial infections}

These cause a substantial burden of disease in the HIV -infected population. E.coli [32] is the bacteria living in the lower intestines of mammals, known as gut flora. It causes diarrhoea, urinary tract infections, neonatal meningitis, and intestinal diseases [33].

MAC (Mycobacterium Avium Complex): Mycobacterium Avium Complex is a bacterial infection that can cause recurring fevers, general sick feelings, problems with digestion, and serious weight loss.

Tuberculosis (TB): Tuberculosis (TB) remains one of the world's top ten leading causes [34] of death. It is caused by a bacterium called Mycobacterium tuberculosis. Tuberculosis is the predominant fatal and unfavorable coinfection [35]. It is a bacterial infection that attacks the lungs, but TB bacteria can attack any part of the body and can cause meningitis. Everyone with HIV who tests positive for exposure to TB should be treated. Cholesterol [36] and respiratory infections are likely to occur in AIDS patients mostly in alcohol consumers.
Salmonellosis: Persons infected with human immunodeficiency virus (HIV) have an increased risk of salmonellosis when compared to the general population. Salmonella bacteremia is one manifestation of immunosuppression in patients with HIV infection, and the development of bacteremia represents a frequent and severe complication in AIDS patients. It is also reported that Salmonella enteritiditis iliacus abscess [37] is found to be an advanced HIV disease.

Syphilis: Like, AIDS Syphilis is also a sexually transmitted disease which can cause serious health problems. A bacterium called Treponema pallidum is the causal agent of syphilis. Several bacterial infections [38] are caused by certain microbes like Streptococcus pneumoniae, Haemophilus species, and Staphylococcus aureus.

Pneumonia: Invasive pneumococcal infection is an important cause of morbidity and mortality in HIV-1-infected individuals. B cells play an important role in maintaining serologic memory after infection. IgM memory B cells are significantly reduced in HIV-1-infected patients, who are also known to have an increased risk of invasive pneumococcal infection [39]. Streptococcus pneumoniae [40] is a worldwide pathogen and the leading cause of invasive bacterial respiratory disease in adults and children with HIV infection. It is the most common cause of community acquired pneumoniae, and meningitis [41] is the sixth leading cause of death in the world. Pneumococcal Bacteremia is a common complication of pneumonia, and relapses occur frequently. Persistent generalized lymphadenopathy [42] may be an isolated manifestation of HIV infected person.

\section{Viral infections}

In AIDS infected people many viruses may attack and cause infections or diseases. The viral agents include Herpes simplex, Cytomegalo virus. HIV-infection causes a chronic hyperactivation of the immune system, with the outcome of inflammatory disorders such as liver fibrosis [43] or atherogenesis.

Influenza: The influenza virus is among the most common human respiratory viruses belonging to Orthomyxoviridae [44, 45] family. It mostly influenza infects the epithelial cells of the upper respiratory tract. Influenza is a cause of respiratory illness in adults infected with HIV.

Cytomegalovirus Infection (CMV): CMV causes significant suffering in HIV infected persons worldwide. Symptoms include fever and diarrhoea from CMV colitis, dyspnoea from CMV pneumonitis, and blindness caused by CMV retinitis [46].

Herpes simplex and herpes zoster: Herpes simplex viruses can cause oral herpes (cold sores) or genital herpes. Herpes simplex infections most commonly occur in adult males associated with recurrent Multiforme Erythema [47]. Herpes zoster virus infection is not life-threatening but can be extremely painful. These infections can occur frequently in HIV-infected persons and can cause encephalitis which may be life-threatening.

Hepatitis: Human immunodeficiency virus (HIV) infected patients are at risk of acquiring viral hepatitis [48], due to common routes of transmission. Hepatitis B is potentially a life-threatening liver infection caused by hepatitis B virus [49].Occult hepatitis B virus (HBV) infection is characterized by presence of $\mathrm{HBV}$ infection without detectable hepatitis B surface antigen (HBsAg). Hepatitis B infection is one of the major public health problems globally and is the tenth leading [50] cause of death. Liver disease is now a leading cause of death among HIV-HCV co-infected patients and is becoming an important cause of death among HIV-HBV co-infected patients. The risk of death 
from liver disease is highest in patients co-infected by both HCV and HBV. Hepatitis C virus (HCV) has emerged as an important etiologic agent of liver injury and failure in patients infected with human immunodeficiency virus (HIV). HCV may also lead to liver cirrhosis [51]. Nevirapine therapy [52] or Nevirapine based antiretroviral [53] is used to treat HCV coinfected AIDS patients. HIV patients who are co infected with HBV may rapidly develop decompensated cirrhosis [54] and hence require Liver Transplantation in such individuals.

\section{Parasitic infections or protozoal diseases}

HIV is frequently associated with parasitical infectious diseases mostly in tropical areas, intestinal parasitic [55] diseases in Senegal. These diseases include Pneumocystis carinii pneumonia (PCP), toxoplasmosis, microsporidiosis, cryptosporidiosis, isosporiasis and leishmaniasis can be transmitted by sand flies. AIDS virus is a neurotropic [56] virus and hence several complications arise. Brain infection with toxoplasmosis can cause trouble thinking or symptoms that mimic a stroke. People infected with HIV are also infected with unusual focal brain syndromes [57]. Neurological complications [58] such as AIDS dementia complex and Peripheral neuropathy may occur in the advanced stages of AIDS.

\section{Malignancies or cancers}

A weakened immune system can also lead to other unusual conditions. Lymphoma in brain, cause fever and trouble thinking. Epstein Barr virus -associated tumours [59] occur frequently in patients with AIDS. Among the secondary problems of patients with the human immune deficiency virus (HIV) infection are lymphadenopathy, atypical lymphoproliferations, and malignant transformations of lymphoid, muscle, and epithelial cells caused by infection with Epstein Barr virus (EBV).

Non-Hodgkin lymphoma: Non-Hodgkin lymphoma (NHL) is an aggressive cancer of the lymph system. The lymph system consists of lymphocytes which fight germs in the body. Lymphoma begins when cells in the lymph system [60] change and grow uncontrollably, which may form a tumor. Most breast lymphomas [61] are the non-Hodgkin's type, nearly representing around 70-90\%. Viruses including EpsteinBarr, Cytomegalovirus, and Herpes simplex virus [62] are associated with breast cancer which is a steroid hormone-dependent tumor [63]. Recent studies show that nodular lymphocyte-predominant Hodgkin's lymphoma may evolve into Non-Hodgkin lymphoma [64]. Human T-cell lymphoma virus (HTLV) [65] is estimated to infect 15 million people in the United States.

Kaposi's sarcoma: Sarcoma is the word derived from Greek literature with a meaning 'fleshy excrescence' [66]. It is caused by Human Herpes virus 8. Kaposi's sarcoma [67] is a cancer of the soft tissues which causes brown, reddish, or purple lesions that develop on the skin or in the mouth. Among men, KS was an AIDS defining cancer.

Squamous cell carcinoma: Squamous cell carcinoma is a type of skin cancer, usually occurs on the face, ears, neck, hands, or arm and also spreads to cervical lymph nodes [68]. The exact cause of squamous cell carcinoma is not known, but the human papilloma virus [69] has been implicated. Squamous cell carcinoma of the conjunctiva has been increasing exponentially among AIDS patients. Both males and females are affected. Patients with recurrent squamous cell carcinoma invariably complain of a deep and severe pain around the eye. Symptoms include tumour development in eye, following enucleation of eye for recurrent carcinoma. Squamous cell carcinoma [70] of the head and neck is considered the sixth most common cancer in the world and accounts for $6 \%$ of all cancers.

Cervical cancer: Cervical cancer or cancer of the cervix is seen in women population infected with AIDS. The uterus holds the growing fetus during pregnancy. The cervix connects the lower part of the uterus to the vagina and, with the vagina, forms the birth canal.

In HIV infected children many nutritional deficiencies [71] have been demonstrated. HIV/AIDS patients are prone to the development of not only opportunistic infections but also endocrine disorders such as diabetes mellitus (DM). Metabolic abnormalities such as glucose regulation are seen. The association between HIV infection and diabetes mellitus is poorly understood and complicated by the differential prevalence of risk factors for diabetes mellitus in HIV-infected persons compared with HIV-uninfected persons.

There is no cure to AIDS, a chronic illness [72] but can be a manageable chronic illness when treated with antiretroviral related therapies. There are several adverse side effects with those modes of treatment. At present HIV is being treated by Combination Antiretroviral therapy [73] or highly active antiretroviral therapy Highly Active Antiretroviral Therapy (HAART) [74] is to reduce HIV transmission [75] but is associated with long term side effects. After the treatment with antiretroviral therapy several complications arise such as cardiovascular problems [76], disturbance of lipid metabolism [77], and insulin resistance. Physical activity [78] can improve quality of life and self-efficacy, and increase the CD4 T-lymphocyte count.

\section{Conclusion}

AIDS is a major disease caused by Human Immunodeficiency Virus. The virus targets the host's defense mechanisms and hence other pathogens make their entry with ease. Several pathogens often attack the weakened immune system but do not affect healthy individuals with potential immune system. The opportunistic infections and malignancies related to AIDS/HIV have been discussed in the present review. People infected with AIDS are mainly the sufferers of opportunistic diseases apart from AIDS alone. Also the treatments of AIDS with various therapies lead to other opportunistic infections.

\section{References}

1. http://www.emedicinehealth.com/hivaids/article_em.htm

2. Pande PP (2009) Computational Approach towards designing potential HIV inhibitors. J Antivir Antiretrovir 1: 82-85.

3. Vandevanter N, Duncan A, Raveis VH, Birnbaum J, Burrell-Piggott $\mathrm{T}$, et al (2011) Continued Sexual Risk Behaviour in African American and Latino Maleto-Female Transgender Adolescents Living with Hiv/Aids: A Case Study. J AIDS Clinic Res S1: 2.

4. http://www.ncbi.nlm.nih.gov/pubmedhealth/PMH0001620/

5. Hu Y, Liang S, Zhu J, Qin G, Liu Q, et al. (2011) Factors Associated with Recent Risky Drug Use and Sexual Behaviors among Drug Users in Southwestern China. J AIDS Clinic Res 2: 120.

6. Achhra AC, Zhou J, Dabis F, Pujari S, Thiebaut R, et al. (2010) Difference in Absolute CD4+ Count According to CD4 Percentage between Asian and Caucasian HIV-Infected Patients. J AIDS Clinic Res 1: 101.

7. Tan DBA, Yong YK, Tan HY, French M, Kamarulzaman A, et al. (2010) Characteristics of Natural Killer Cells in Malaysian HIV Patients Presenting with Immune Restoration Disease After ART. J AIDS Clinic Res 1: 102

8. Guha P, Sardar P (2011) Prevalence of Paediatric HIV Infection in Eastern India-First report. J AIDS Clinic Res 2: 127.

9. Millar AJW, Van As AB, Numanoglu A, Cywes S (2011) Sexual Assaults in Children: The Role of HIV Post-Exposure Prophylaxis. J AIDS Clinic Res 2 116. 
10. Neurath AR, Lackman-Smith C (2009) Prevention of Human Immunodeficiency Virus Type 1 Transmission by Pharmaceuticals Targeted to Host Proteins Required for Virus Infection? Consideration of Farnesyl Thiosalicylic Acid, a Ras Inhibitor. J Antivir Antiretrovir 1: 72- 75.

11. Amare B, Tafess K, Ota F, Moges F, Moges B, et al. (2011) Serum Concentration of Selenium in Diarrheic Patients with and without HIVIAIDS in Gondar, Northwest Ethiopia. J AIDS Clinic Res 2: 128.

12. Nsimba SED, Irunde H, Comoro C (2010) Barriers to ARV Adherence among HIVIAIDS Positive Persons taking Anti-Retroviral Therapy in Two Tanzanian Regions 8-12 Months after Program Initiation. J AIDS Clinic Res 1: 111.

13. Reginald OO, Mohammed MH, Olayinka AT, Sani GB, Tobi-Ajayi E, et al. (2011) Hematological and Metabolic Toxicities of Current Antiretroviral Regimens in Ahmadu Bello University Teaching Hospital Shika Zaria, Northern Nigeria. J AIDS Clinic Res S2: 2.

14. Chaisson, Richard E, Gallant JE, Keruly JC, Moore RD (1998) Impact of Opportunistic Disease on Survival in Patients with HIV Infection. AIDS 12: 2933.

15. Jeffrey L. Jones, Debra L. Hanson, Mark S. Dworkin et al. (1998) Trends in AIDS-Related Opportunistic Infections among Men Who Have Sex with Men and among Injecting Drug Users, 1991-1996. The Journal of Infectious Diseases 178: 114-20.

16. Kumarasamy N, Solomon S, Jayaker Paul SA, Venilla R, Amalraj RE (1995) Spectrum of Opportunistic Infections among AIDS Patients in Tamil Nadu, India. Int J STD AIDS 6: 447-449.

17. Sudano I, Spieker LE, Noll G, Corti R, Weber R (2006) Cardiovascular Disease in HIV Infection. Am Heart J 151: 1147-1155.

18. Ances BM, Ellis RJ (2007) Dementia and Neurocognitive Disorders due to HIV1 Infection. Semin Neurol 27: 86-92.

19. Moanna A, Skarbinski J, Kalokhe AS, Rimland D, Rouphael NG (2011) Primary Human Immunodeficiency Virus Infection and Rhabdomyolysis. J AIDS Clinic Res 2: 119.

20. Bodhade AS, Ganvir SM, Hazarey VK (2011) Oral Manifestations of HIV Infection and their Correlation with CD4 Count. J Oral Sci 53: 203-211.

21. Corrêa RB, Schmidt FR, Silva MLCF, Costa FHR, Rosso AL, et al. (2010) Holmes' Tremor in an HIV Positive Patient Worsened by Immune Recovery Inflammatory Syndrome (IRIS). J AIDS Clinic Res 1: 105.

22. Patel AK, Patel KK, Ranjan R, Patel AR, Patel JK (2010) Seronegative HIV-1 Infection, a Difficult Clinical Entity; a Case Report. J AIDS Clinic Res 1: 106.

23. Hu G, Wang J, Choi J, Jung WH, Liu I et al (2011) Variation in Chromosome Copy Number Influences the Virulence of Cryptococcus neoformans and Occurs in Isolates from AIDS Patients. BMC Genomics 12: 526

24. Peigne V, Dromer F, Elie C, Lidove O, Lortholary O, et al. (2011) Imported Acquired Immunodeficiency Syndrome-Related Histoplasmosis in Metropolitan France: A Comparison of Pre-Highly Active Anti-Retroviral Therapy and Highly Active Anti-Retroviral Therapy Eras Am J Trop Med Hyg 85: 934-941.

25. Roy D, Guha P, Bandyopadhyay D, Sardar P, Chatterjee SK (2011) Pancytopenia with Hemophagocytic Syndrome Associated with Histoplasmosis in Acquired Immunodeficiency Syndrome: Description of 2 Case Studies and Literature Review. J AIDS Clinic Res 2: 115.

26. Ehui E, Doukouré B, Kolia-Diafouka P, Aoussi E, Koffi E, et al. (2011) Intestina Histoplasmosis with Histoplasma duboisii in a Patient Infected by HIV-1 in Abidjan (Ivory Coast). J AIDS Clinic Res 2: 125.

27. Alonso JLP, Tellez F, Perez M, Moncada SL, Miragaya D, et al. (2011) Amphotericin B as Alternative to Itraconazole in Secondary Prophylaxis of Neurohistoplasmosis in HIV-Positive Patients with Antiretroviral Therapy. J AIDS Clinic Res 2: 121

28. Ray A, Ray S, George AT, Swaminathan N (2011) Interventions for prevention and treatment of vulvovaginal candidiasis in women with HIV infection. Cochrane Database Syst Rev.

29. Farage MA, Miller KW, Gerberick GF, Saito FH, Ledger WJ, et al. (2011) Innate Immunity in the Lower Female Mucosal Tract. J Steroids Hormon Sci 2: 106

30. Corr PD (2011) Musculoskeletal Fungal Infections. Semin Musculoskele Radiol 15: 506-510.
31. Khoo SH, Denning DW (1994) Invasive Aspergillosis in Patients with AIDS. Clin Infect Dis 1: S41-48.

32. Tobit V, Verma OP, Ramteke PW, Ray RS (2011) Phototoxic Assesment of Polycyclic Aromatic Hydrocarbons by Using NIH-3T3 and L-929 Cell Lines. J AIDS Clinic Res 2: 123

33. Rajpal SK, Snehal SW, Milind SP, Hemant JP, Girdhar MT, et al. (2011) Mycobacterium Tuberculosis Heat Shock Protein 16 as a Potential Marker for Latent TB: A Preliminary Findings. J Clin Cell Immunol 2: 115.

34. Arjanova OV, Prihoda ND, Yurchenko LV, Sokolenko NI, Vihrova LA, et al (2009) Impact of Adjunct Immunotherapy with Multi-herbal Supplement Dzherelo (Immunoxel) on Treatment Outcomes in End-stage TB/HIV Patients. J Antivir Antiretrovir 1: 86-88.

35. Míguez MJ, Rosenberg R, Burbano X, Malow R (2011) Cholesterol as a Mediator of Alcohol-Induced Risks for Respiratory Disease Hospitalizations among People Living With HIV. J AIDS Clinic Res S1: 1.

36. Mentzer A, Karalliedde J, Williams H, Guzder R, Ranja babu K (2010) Backache with Fever: A Unique Presentation of Advanced HIV Infection. J AIDS Clinic Res 1: 104.

37. Witt DJ, Craven DE, McCabe WR (1987) Bacterial Infections in Adult Patients with the Acquired Immune Deficiency Syndrome (AIDS) and AIDS-related Complex. Am J Med 82: 900-906.

38. Hart M, Steel A, Clark SA, Moyle G, Nelson M, et al. (2007) Loss of Discrete Memory B cell Subsets is Associated with Impaired Immunization Responses in HIV-1 Infection and may be a Risk Factor for Invasive Pneumococcal Disease. $\mathrm{J}$ Immunol 178: 8212-8220.

39. Norcross EW, Sanders ME, Moore QC 3rd, Marquart ME (2011) Pathogenesis of A Clinical Ocular Strain of Streptococcus pneumoniae and the Interaction of Pneumolysin with Corneal Cells. J Bacteriol Parasitol 2: 108.

40. Shaper M (2011) Antibiotic Resistance in Streptococcus pneumonia: A Disaster in the making. Epidemiol 1: 102e.

41. Ballet JJ, Sulcebe G, Couderc LJ, Danon F, Lathrop M, et al. (1987) Impaired Anti-pneumococcal Antibody Response in Patients with AIDS-related Persisten generalized Lymphadenopathy. Clin Exp Immunol 68: 479-487.

42. Pineda JA, Alcamí J, Blanco JR, Blanco J, Boix V, et al. (2011) Hot Immunologica Topics in HIV Infection. J AIDS Clinic Res 2: 118

43. Wee T, Jenssen H (2009) Influenza Drugs - Current Standards and Nove Alternatives. J Antivir Antiretrovir 1: 1-10.

44. Sheth AN, Althoff KN, Brooks JT (2011) Influenza Susceptibility, Severity and Shedding in HIV-Infected Adults: A Review of the Literature. Clin Infect Dis. 52 219-227.

45. Emina MO, Odjimogho SE (2010) Ocular Problems in HIV and AIDS Patients in Nigeria. Optom Vis Sci 87: 979-984.

46. Blyta Y, Kocinaj A, Ferizi M, Gerqari A, Ahmeti N (2011) Multiforme Erythema, In Child, After Repeated Herpes Simplex Infections - Case Presentation. J Clin Exp Dermatol Res 2: 127

47. Ramezani A, Banifazl M, Mohraz M, Rasoolinejad M, Aghakani A (2011) Occult Hepatitis B Virus Infection. A Major Concern in HIV-Infected Patients: Occult HBV in HIV. Hepat Mon 11: 7-10.

48. Vijai S, Indramani, Dharmendra KC, Pallavi S (2009) HLA Class I and II Binding Promiscuity of the T-cell Epitopes in Putative Proteins of Hepatitis B Virus. J Comput Sci Syst Biol 2: 69-73.

49. Singhal V, Bora D, Singh S (2011) Prevalence of Hepatitis B Virus Infection in Healthcare Workers of a Tertiary Care Centre in India and Their Vaccination Status. J Vaccines Vaccin 2: 118.

50. Ramsey SE, Engler PA, Stein MD, Brown RA, Cioe P et al. (2011) Effect of CB on Depressive Symptoms in Methadone Maintenance Patients Undergoing Treatment for Hepatitis C. J Addict Res Ther 2: 109.

51. Mira JA, López-Cortés LF, Vispo E, Tural C, Laguno M, et al. (2010) Concomitan Nevirapine Therapy is Associated with Higher Efficacy of Pegylated Interferon Plus Ribavirin among HIV/Hepatitis C Virus-Coinfected Patients. J AIDS Clinic Res 1: 112.

52. Mata RC, Mira JA, Rivero A, López-Cortés LF, Torres-Tortosa M, et al. (2010) Nevirapine-based Antiretroviral Therapy is Associated with Lower Plasma Hepatitis C Virus Viral Load among HIV/Hepatitis C Virus-Coinfected Patients. J AIDS Clinic Res 1: 110 
Citation: Soumya D, Hima Bindu A (2011) Opportunistic Diseases as a Consequence of HIVIAIDS. J AIDS Clinic Res 2:133. doi:10.4172/21556113.1000133

53. Mukherjee S (2009) Antiviral Therapy for Hepatitis B in Pre and Post-liver Transplant Patients. J Antivir Antiretrovir 1: 17-27.

54. Faye B, Tine RC, Ndiaye JL, Kintega C, Manga NM, et al. (2010) Impact of Intestinal Parasites on Intensity of HIV Infection in Senegal. J Antivir Antiretrovir 1: 11-12.

55. Sardar P, Guha P, Roy D, Bandyopadhyay D, Chatterjee SK (2011) "Multiple Sclerosis like Demyelination in Early HIV Infection-A Rare Presentation": Case Report and Literature Review. J AIDS Clinic Res 2: 124

56. Uriel A, Stow R, Johnson L, Varma A, du Plessis D et al (2010) Tumefactive Demyelination-An Unusual Neurological Presentation of HIV. Clin Infect Dis 51: 1217-1220.

57. Price RW, Brew B, Sidtis J, Rosenblum M, Scheck AC et al. (1988) The Brain in AIDS: Central Nervous System HIV-1 Infection and AIDS Dementia Complex. Science 239: 586-592.

58. MacMahon EM, Glass JD, Hayward SD, Mann RB, Becker PS et al. (1991) Epstein-Barr Virus in AIDS-Related Primary Central Nervous System Lymphoma. Lancet 338: 969-973.

59. Skogseth H, Tvedt KE, Halgunset J (2011) Carcinoma Metastasis-An Approach to Models. J Carcinogene Mutagene 2: 119.

60. Nigam A, Singh AK, Singh SK, Singh N, Singh N, et al. (2011) Primary Mammary (Non-Hodgkin) Lymphoma of Breast: A Case Report. J Cancer Sci Ther 3: 173-175.

61. Kingsley K, Zuckerman J, Davis M, Matteucci M, Knavel A, et al. (2009) Induction of Differential Growth in vitro by Highrisk Human Papillomavirus in Human Breast Cancer Cell Lines is Associated with Caspase Dysregulation. J Cancer Sci Ther 1: 62-71.

62. Jamil K, Kumar K, Fatima SH, Rabbani S, Kumar R, et al. (2009) Clinical Studies on Hormonal Status in Breast Cancer and its Impact on Quality of Life (QOL). J Cancer Sci Ther 1: 83-89.

63. Riley JM, Jenrette JM, Gordon L, Milligan L, Zauls AJ, et al. (2011) Progression of Nodular Lymphocyte-Predominant Hodgkin's Lymphoma to a High-Grade Lymphoma. J Cell Sci Ther S2: 1.

64. Harring TR, Nguyen NT, Goss JA, O'Mahony CA (2011) Human T-Cell Lymphoma Virus-Positive Allograft Used For Effective Orthotopic Live Transplantation: A Case Report and Review of the Literature. J Transplant Technol Res 1: 102.

65. Khorate MM, Goel S, Singh MP, Ahmed J (2010) Osteosarcoma of Mandible: A Case Report and Review of Literature. J Cancer Sci.Ther 2: 122-125.
66. Essadi I, Sbitti Y, Ichou M, Errihani H (2011) The Role of Chemotherapy in the Treatment of Kaposi's Sarcoma. J Cancer Sci Ther 3: 145-148.

67. Ammer AG, Kelley LC, Hayes KE, Evans JV, Lopez-Skinner LA, et al. (2009) Saracatinib Impairs Head and Neck Squamous Cell Carcinoma Invasion by Disrupting Invadopodia Function. J Cancer Sci Ther 1: 52-61.

68. Solomon Guramatunhu (2003) Squamous Cell Carcinoma in HIVIAIDS Community Eye Health 16: 37.

69. Delouya G, Clavel S, El-Bared N, Soulières D, Fortin B, et al. (2011) Induction Chemotherapy Followed by Concomitant Chemoradiation in Head and Neck Squamous Cell Carcinoma: A Single Institution Experience. Otolaryngol 1: 108.

70. Lipshultz SE, Mas CM, Miller TL, Cordero C, Dauphin D, et al. (2011) The Effects of Fetal and Childhood Exposure to Antiretroviral Agents. J AIDS Clinic Res S2: 1

71. Sai YRKM, Dattatreya A, Anand SY, SureshBabu D, Sandeep Heni RS (2011) Biomarkers of Internal Origin and Their Significance in Diabetes and Diabetic Complications. J Diabetes Metab R1: 1

72. Pinola M, Lazzarin A, Antinori A, Carosi G, Di Perri G, et al. (2010) Lopinavir/ ritonavir + tenofovir Dual Therapy versus Lopinavir/ritonavir- Based Triple Therapy in HIV-Infected Antiretroviral Naïve Subjects: The Kalead Study. J Antivir Antiretrovir 2: 56-62

73. Soe AN, Tansuphasawadikul S, Phonrat B, Boonpok L, Tepsupa S, et al. (2010) Early Viral Suppression Predicting Long-term Treatment Success Among HIV Patients Commencing NNRTI-based Antiretroviral Therapy. J Antivir Antiretrovir 2: 33-37.

74. Herzmann C, Smith C, Johnson MA, Byrne P, Terenghi G, et al. (2010) A Prospective, Double Blind, Randomised, Placebo Controlled Trial Evaluating Acetyl-L-Carnitine (ALCAR) for the Prevention of Distal Symmetric Polyneuropathy in HIV Infected Individuals. J AIDS Clinic Res 1: 108.

75. Thomas Kerr WS (2011) HIV Treatment as Prevention and the Role of Applied Social Science Research. J AIDS Clinic Res 2: 102e.

76. Bhardwaj A, Parikh R, Daoko J, Singh L, Shamoon FE, et al. (2009) Cardiovascular Manifestation of HIV: Review. J Antivir Antiretrovir 1: 11-16.

77. Gontran M, Jerome LT, Yvonne AM, Mavoungou-Poaty V, Elie M, et al. (2009) Effects of IM28 on HIV-1 and Metabolic Disorders-induced Highly Active Antiretroviral Therapy in Gabonese Patients. J Antivir Antiretrovir 1: 76-81.

78. Santos-Lozano A, Garatachea N (2011) Physical Activity Measurements Using Accelerometers and Pedometers in HIV-Infected People. J AIDS Clinic Res 2 126. 